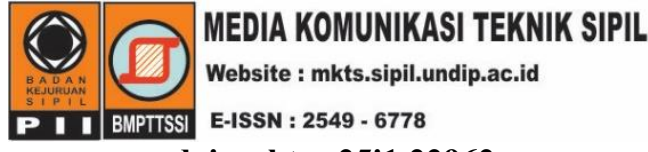

doi: mkts.v25i1.22962

\title{
Kajian Pemilihan Koefisien Situs pada Perhitungan Spektra Percepatan Gerakan Tanah di Permukaan
}

\author{
"Windu Partono', Masyhur Irsyam², I. Wayan Sengara², Muhammad Asrurifak ${ }^{3}$ \\ ${ }^{1}$ Fakultas Teknik, Universitas Diponegoro, Semarang, \\ ${ }^{2}$ Fakultas Teknik Sipil dan Lingkungan, Institut Teknologi Bandung, Bandung, \\ ${ }^{3}$ Pusat Penelitian Mitigasi Bencana, Institut Teknologi Bandung, Bandung \\ ${ }^{*}$ windupartono@ lecturer.undip.ac.id
}

Received: 30 April 2019 Revised: 3Juli 2019 Accepted: 5 Juli 2019

\begin{abstract}
SNI 1726:2012 states that surface spectral accelerations $S_{M S}\left(0.2\right.$ second) and $S_{M 1}$ (1 second) can be calculated by multiplying site factors $F a\left(0.2\right.$ second) and $F v\left(1\right.$ second) with spectral accelerations $S_{S}(0.2$ second) dan $S_{1}$ (1 second). All site factors used by SNI 1726:2012 are adopted from ASCE/SEI 7-10. In 2013 Stewart and Seyhan proposed new and different site factors compared to ASCE/SEI 7-10. These site factors are then used for developing ASCE/SEI 7-16 with minor improvement for site class SE (soft soil). ASCE/SEI 7-16 states that the site factors for site class $S E$ with $S_{S}$ greater than $1 \mathrm{~g}$ or $S_{1}$ greater than $0.2 \mathrm{~g}$, shall be calculated using Site Specific Analysis (SSA). The SSA method used for calculating site factor is difficult for ASCE/SEI 7-16 to be implemented in Indonesia. This paper describes the result of $S_{M S}$ and $S_{M 1}$ study at five cities (Jakarta, Bandung, Semarang, Yogyakarta and Surabaya) for site class SC, SD and SE using site factors proposed by Stewart and Seyhan and site factor SNI 1726:2012. The $S_{M S}$ and $S_{M 1}$ at five cities calculated using site factors proposed by Stewart and Seyhan are $\pm 15 \%$ differences compared to $S_{M S}$ and $S_{M 1}$ calculated using SNI 1726:2012 site factors.
\end{abstract}

Keywords: Site factor, surface spectral acceleration, site specific analysis

\begin{abstract}
Abstrak
SNI 1726:2012 menjelaskan bahwa spektra percepatan permukaan $S_{M S}\left(0,2\right.$ detik) dan $S_{M 1}$ (1 detik) dapat dihitung dengan mengalikan koefisien situs $\mathrm{Fa}\left(0,2\right.$ detik) dan $\mathrm{Fv}$ (1 detik) dengan spektra percepatan $S_{S}(0,2$ detik) dan $S_{1}$ (1 detik). Koefisien situs yang digunakan oleh SNI 1726:2012 diadopsi dari ASCE/SEI 7-10. Pada tahun 2013 Stewart dan Seyhan menyampaikan usulan koefisien situs baru yang berbeda dengan yang digunakan pada ASCE/SEI 7-10. Koefisien situs tersebut kemudian digunakan pada pengembangan ASCE/SEI 7-16 dengan sedikit perubahan pada situs tanah SE. ASCE/SEI 7-16 menyampaikan bahwa untuk kelas situs SE jika nilai $S_{S}$ lebih besar dari 1,0g atau nilai $S_{1}$ lebih besar dari 0,2g maka koefisien situs harus ditentukan dengan metode Site Specific Analysis (SSA). Penggunaan metode SSA menyebabkan ASCE/SEI 7-16 sulit diterapkan di Indonesia. Tulisan ini menyampaikan hasil kajian penggunaan koefisien situs dari Stewart dan Seyhan dan koefisien situs SNI 1726:2012 pada perhitungan spektra percepatan permukaan $S_{M S}$ dan $S_{M 1}$ pada lima kota (Jakarta, Bandung, Semarang, Yogyakarta dan Surabaya) untuk situs tanah SC, SD dan SE. Hasil kajian menunjukkan $S_{M S}$ dan $S_{M 1}$ yang dihitung pada lima kota dengan koefisien situs dari Stewart dan Seyhan berbeda $\pm 15 \%$ dibandingkan jika menggunakan koefisien situs SNI 1726:2012.
\end{abstract}

Kata kunci: Koefisien situs, spektra percepatan permukaan, site specific analysis

\section{Pendahuluan}

Peta Sumber dan Bahaya Gempa Indonesia telah terbit pada tahun 2017. Peta tersebut merupakan pengembangan Peta Sumber Gempa Tahun 2010. Penelitian dan pengembangan Peta Sumber dan
Bahaya Gempa Indonesia tahun 2017 dilakukan oleh Pusat Studi Gempa Nasional (PUSGEN, 2017). Perubahan terbesar dari peta gempa tahun 2017 terhadap peta gempa tahun 2010 adalah bertambahnya jumlah sumber gempa terutama sumber gempa sesar aktif yang tersebar di seluruh 
wilayah Indonesia. Sebagai contoh jalur sesar aktif di Pulau Jawa yang terdeteksi menurut hasil penelitian pada tahun 2010 berjumlah 5 (Partono et al., 2015).

Berdasarkan hasil penelitian terbaru yang tertuang pada peta gempa tahun 2017 jumlah sesar aktif yang terdeteksi di Pulau Jawa berubah menjadi 31 jalur. Berbeda dengan sumber gempa sesar aktif, sumber gempa subduksi tidak mengalami perubahan secara signifikan. Dampak terpenting dari hasil penelitian dan pengembangan Peta Gempa tahun 2017 adalah evaluasi terhadap SNI 1726:2012 (Tata cara perencanaan ketahanan gempa untuk struktur bangunan gedung dan non gedung). Informasi penting yang perlu dievaluasi adalah peta $\mathrm{MCE}_{\mathrm{R}}$ (risk-targeted maximum considered earthquake) di batuan dasar $(\mathrm{SB})$ baik untuk periode pendek $\left(\mathrm{S}_{\mathrm{S}}\right)$ dan periode panjang $\left(S_{1}\right)$.

Nilai $M_{C} E_{R} S_{S}$ dan $S_{1}$ sangat diperlukan pada perhitungan spektra percepatan dipermukaan $\left(S_{M S}\right.$ dan $S_{M 1}$ ) maupun spektra percepatan desain ( $S_{D S}$ dan $S_{\mathrm{D} 1}$ ). Perhitungan $\mathrm{S}_{\mathrm{MS}}$ dan $\mathrm{S}_{\mathrm{M} 1}$ membutuhkan informasi tentang nilai atau koefisien situs $\mathrm{Fa}$ (periode pendek/0,2 detik) dan Fv (periode panjang/1 detik). Koefisien situs Fa dan Fv yang tercantum pada SNI 1726:2012 mengadopsi secara langsung dari peraturan ASCE/SEI 07-10 (minimum design loads for buildings and other structures). ASCE/SEI 07-10 telah berkembang menjadi ASCE/SEI 7-16.

Pengembangan ASCE/SEI 7-16 memberikan dampak langsung terhadap pengembangan SNI 1726:2012. Salah satu dampak terpenting dari pengembangan ASCE/SEI 7-16 adalah cara perhitungan koefisien situs $\mathrm{Fa}$ dan $\mathrm{Fv}$ terutama untuk situs tanah SE (tanah lunak). Untuk situs tanah SE dengan nilai $\mathrm{S}_{\mathrm{S}}$ minimum $1,0 \mathrm{~g}$, nilai $\mathrm{Fa}$ tidak dapat dihitung menggunakan tabel koefisien situs tetapi harus dihitung dengan pendekatan metode respons spesifik-situs (site specific
analysis/SSA). Pendekatan yang sama juga harus dilakukan pada perhitungan koefisien situs Fv pada situs $\mathrm{SE}$ jika nilai $\mathrm{S}_{1}$ minimum $0,2 \mathrm{~g}$.

Persoalan penting yang harus dihadapi pada pengembanagan SNI 1726:2012 sekiranya akan mengabdopsi ASCE/SEI 7-16 adalah penggunaan metode SSA pada perhitungan koefisien situs $\mathrm{Fa}$ dan Fv untuk kelas situs SE. SSA sangat sulit dilaksanakan oleh para ahli dibidang Teknik Sipil karena membutuhkan data elevasi batuan dasar (bedrock), data dinamis tanah (kecepatan rambat gelombang geser/VS, density tanah $/ \gamma$, modulus geser/G dan damping ratio/ $/$ ) setiap lapisan tanah sampai ke permukaan (Shiuly et al., 2017; Irsyam et al., 2007)

Dua peneliti Stewart \& Seyhan (2013) yang tergabung pada Pasific Earthquake Engineering Research (PEER) memperkenalkan koefisien situs yang berbeda dengan koefisien situs yang digunakan pada ASCE/SEI 07-10. Koefisien situs tersebut kemudian digunakan pada ASCE/SEI 7-16. Tabel 1 dan 2 menunjukkan koefisien situs Fa dan Fv hasil penelitian Stewart \& Seyhan (2013). Koefisien situs SA (Batuan keras), SB (batuan), SC (tanah keras) dan SD (tanah sedang) yang digunakan pada ASCE/SEI 7-16 sama dengan hasil penelitian Stewart \& Seyhan (2013). ASCE/SEI 716 menggunakan cara berbeda untuk perhitungan koefisien situs tanah SE. Tabel 3 dan 4 menunjukkan cara perhitungan koefisien situs yang digunakan ASCE/SEI 7-16 untuk situs tanah SE. Pada kedua tabel tersebut terlihat bahwa metode SSA harus digunakan untuk mendapatkan nilai koefisien situs pada situs tanah $\mathrm{SE}$ jika nilai $\mathrm{S}_{\mathrm{S}}$ minimum $1,0 \mathrm{~g}$ atau nilai $\mathrm{S}_{1}$ minimum $0,2 \mathrm{~g}$. Tulisan ini akan menyajikan hasil kajian perhitungan spektra percepatan permukaan $\mathrm{S}_{\mathrm{MS}}$ dan $\mathrm{S}_{\mathrm{M} 1}$ pada lima kota besar di Pulau Jawa (Jakarta, Bandung, Semarang, Yogyakarta dan Surabaya) dengan menggunakan koefisien situs dari Stewart \& Seyhan (2013).

Tabel 1. Koefisien situs Fa (Stewart \& Seyhan, 2013)

\begin{tabular}{ccccccc}
\hline Situs & $\mathbf{S}<\mathbf{0 , 2 5}$ & $\mathbf{S}_{\mathbf{S}}=\mathbf{0 , 5}$ & $\mathbf{S}_{\mathbf{S}}=\mathbf{0 , 7 5}$ & $\mathbf{S}_{\mathbf{S}}=\mathbf{1 , 0}$ & $\mathbf{S}_{\mathbf{S}}=\mathbf{1 , 2 5}$ & $\mathbf{S}_{\mathbf{S}}>\mathbf{1 , 5}$ \\
\hline SA & 0,8 & 0,8 & 0,8 & 0,8 & 0,8 & 0,8 \\
SB & 0,9 & 0,9 & 0,9 & 0,9 & 0,9 & 0,9 \\
SC & 1,3 & 1,3 & 1,2 & 1,2 & 1,2 & 1,2 \\
SD & 1,6 & 1,4 & 1,2 & 1,2 & 1,0 & 1,0 \\
SE & 2,4 & 1,7 & 1,3 & 1,1 & 0,9 & 0,8 \\
\hline
\end{tabular}

Tabel 2. Koefisien situs Fv (Stewart \& Seyhan, 2013)

\begin{tabular}{ccccccc}
\hline Situs & $\mathbf{S}_{\mathbf{1}}<\mathbf{0 , 1}$ & $\mathbf{S}_{\mathbf{1}}=\mathbf{0 , 2}$ & $\mathbf{S}_{\mathbf{1}}=\mathbf{0 , 3}$ & $\mathbf{S}_{\mathbf{1}}=\mathbf{0 , 4}$ & $\mathbf{S}_{\mathbf{1}}=\mathbf{0 , 5}$ & $\mathbf{S}_{\mathbf{1}}>\mathbf{0 , 6}$ \\
\hline SA & 0,8 & 0,8 & 0,8 & 0,8 & 0,8 & 0,8 \\
SB & 0,8 & 0,8 & 0,8 & 0,8 & 0,8 & 0,8 \\
SC & 1,5 & 1,5 & 1,5 & 1,5 & 1,5 & 1,4 \\
SD & 2,4 & 2,2 & 2,0 & 1,9 & 1,8 & 1,7 \\
SE & 4,1 & 3,3 & 2,8 & 2,4 & 2,2 & 2,0 \\
\hline
\end{tabular}


Tabel 3. Koefisien situs Fa (ASCE/SEI 7-16)

\begin{tabular}{ccccccc}
\hline SituS & $\mathbf{S}_{\mathbf{S}}<\mathbf{0 , 2 5}$ & $\mathbf{S}_{\mathbf{S}=\mathbf{0 , 5}}$ & $\mathbf{S}_{\mathbf{S}=\mathbf{0 , 7 5}}$ & $\mathbf{S}_{\mathbf{S}=\mathbf{1 , 0}}$ & $\mathbf{S}_{\mathbf{S}}=\mathbf{1 , 2 5}$ & $\mathbf{S}_{\mathbf{S}}>\mathbf{1 , 5}$ \\
\hline $\mathrm{SE}$ & 2,4 & 1,7 & 1,3 & $\mathrm{SSA}$ & $\mathrm{SSA}$ & $\mathrm{SSA}$ \\
\hline
\end{tabular}

Tabel 4. Koefisien situs Fv (ASCE/SEI 7-16)

\begin{tabular}{ccccccc}
\hline Situs & $\mathbf{S}_{\mathbf{1}}<\mathbf{0 , 1}$ & $\mathbf{S}_{\mathbf{1}}=\mathbf{0 , 2}$ & $\mathbf{S}_{\mathbf{1}}=\mathbf{0 , 3}$ & $\mathbf{S}_{\mathbf{1}}=\mathbf{0 , 4}$ & $\mathbf{S}_{\mathbf{1}}=\mathbf{0 , 5}$ & $\mathbf{S}_{\mathbf{1}}>\mathbf{0 , 6}$ \\
\hline SE & 4,1 & SSA & SSA & SSA & SSA & SSA \\
\hline
\end{tabular}

Hasil perhitungan nilai $S_{M S}$ dan $S_{M 1}$ pada kelima kota tersebut kemudian dibandingkan dengan nilai $\mathrm{S}_{\mathrm{MS}}$ dan $\mathrm{S}_{\mathrm{MI}}$ yang dihitung dengan menggunakan koefisien situs dari SNI 1726:2012. Pada tulisan ini juga disampaikan tahapan perhitungan $S_{M S}$ dan $S_{M 1}$ berdasarkan kombinasi data hazard gempa probabilistik dan determinstik untuk mendapatkan nilai $\mathrm{MCE}_{\mathrm{R}} \mathrm{S}_{\mathrm{S}}$ dan $\mathrm{S}_{1}$.

\section{Metode}

Analisis untuk mendapatkan nilai spektra percepatan tanah dengan menggunakan kombinasi hazard gempa probabilistik (probabilitic seismic hazard analysis/PSHA) dan deterministik (deterministic seismic hazard analysis/DSHA) pertama kali diperkenalkan oleh Leyendecker et al. (2000). Perhitungan percepatan gerakan tanah di batuan dasar pada satu titik dengan pendekatan PSHA dilakukan dengan menggunakan metode total probability theorem dari McGuire (1995).

Persamaan 1 menunjukkan rumus dasar perhitungan spektra percepatan dengan pendekatan probabilistik. Nilai " $\lambda \mathrm{a}$ *" pada Persamaan 1 menunjukkan total probabilitas terlampaui nilai percepatan "a*". $\mathrm{P}_{\mathrm{m}}(\mathrm{m})$ dan $\mathrm{P}_{\mathrm{r}}(\mathrm{r})$ adalah probabilitas fungsi distribusi magnitudo " $\mathrm{m}$ " dan jarak " $r$ " sedangkan "v" adalah nilai tengah kecepatan (antara batas bawah dan batas atas). Untuk perhitungan PSHA digunakan pendekatan probabilitas $2 \%$ terlampaui selama 50 tahun atau periode ulang gempa 2500 tahun. Analisis deterministik DSHA untuk setiap titik pengamatan dihitung dengan menggunakan nilai magnitudo gempa terbesar atau magnitudo rencana dari setiap sumber gempa dan jarak terdekat titik pengamatan terhadap setiap sumber gempa.

$\lambda \mathrm{a}^{*}=\mathrm{v} \int_{\mathrm{m}} \int_{\mathrm{r}}(\mathrm{Pa}>\mathrm{a} * \mid \mathrm{m}, \mathrm{r}) \mathrm{P}_{\mathrm{m}}(\mathrm{m}) \mathrm{P}_{\mathrm{r}}(\mathrm{r}) \mathrm{dr} \mathrm{dm}$

Untuk menghitung percepatan gerakan tanah di batuan dasar dengan pendekatan PSHA dan DSHA digunakan beberapa fungsi atenuasi atau GMPE (ground motion prediction equation). GMPE yang digunakan untuk perhitungan spektra percepatan di batuan dasar dikelompokkan menjadi empat kelompok model yaitu shallow crustal fault, shallow background, subduksi megathrust dan subduksi Benioff. GMPE yang digunakan untuk model sumber gempa shallow crustal fault sama dengan model shallow background yaitu Boore \& Atkinson (2008), Campbell \& Bozorgnia (2008) dan Chiou \& Youngs (2008). GMPE untuk model sumber gempa subduksi megathrust adalah Abrahamson et al. (2016), Zhao et al. (2006) dan Atkinson \& Boore (2003). Sedangkan untuk model sumber gempa benioff menggunakan GMPE dari Youngs et al. (1997) dan Atkinson \& Boore (2003).

Perhitungan kombinasi PSHA dan DSHA dilakukan untuk mendapatkan nilai $\mathrm{MCE}_{\mathrm{R}}$ dengan menggabungkan analisis risk targeted ground motion (RTGM) dari PSHA (dengan target probabilitas keruntuhan bangunan $1 \%$ selama 50 tahun) dengan $84^{\text {th }}$ percentile dari DSHA. Pada perhitungan RTGM digunakan nilai logaritma standard deviasi " $\beta$ " sebesar 0,65 dan nilai faktor arah gempa (direction factor) 1,1 untuk spektra 0,2 detik dan 1,3 untuk spektra 1 detik. Pada pembuatan SNI 1726:2012, nilai " $\beta$ ” yang digunakan adalah sebesar 0,7 (Sengara et al., 2015) dan direction factor spektra 0,2 detik dan 1 detik secara berturutturut adalah 1,05 dan 1,15.

Sidi (2011) menyarankan penggunaan nilai " $\beta$ " untuk Indonesia bervariasi antara 0,65 sampai 0,7. Persamaan 2 dan 3 menunjukkan rumus perhitungan RTGM (Luco et al., 2007). Nilai “c" pada persamaan tersebut merupakan nilai percepatan sedangkan " $c_{10 \%}$ " adalah nilai $10^{\text {th }}$ percentile kapasitas keruntuhan bangunan. Gambar 1 menunjukkan skema perhitungan $\mathrm{MCE}_{\mathrm{R}}$ yang merupakan kombinasi dari hasil perhitungan RTGM dan DSHA dan dikembangkan dari metode yang diperkenalkan oleh Leyendecker et al. (2000).

$$
\begin{aligned}
& \mathrm{f}_{\mathrm{F}}(\mathrm{c})=\frac{1}{\mathrm{c} \beta \sqrt{2 \pi}} \exp \left[-\frac{\ln \mathrm{c}-\left(\ln \mathrm{c}_{10 \%}+1.28 \beta\right)^{2}}{2 \beta^{2}}\right] \\
& P[\text { collaps }]=\int_{0}^{\infty} f_{F}(c) P[S>c] d c
\end{aligned}
$$




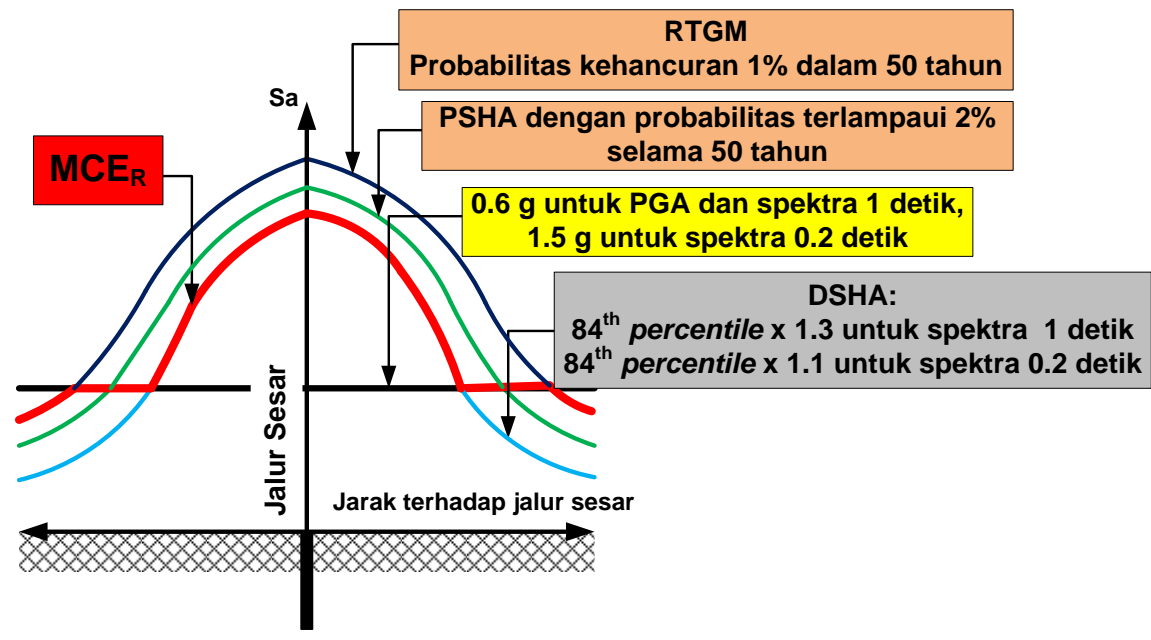

Gambar 1. Skema perhitungan $\mathrm{MCE}_{\mathrm{R}}$

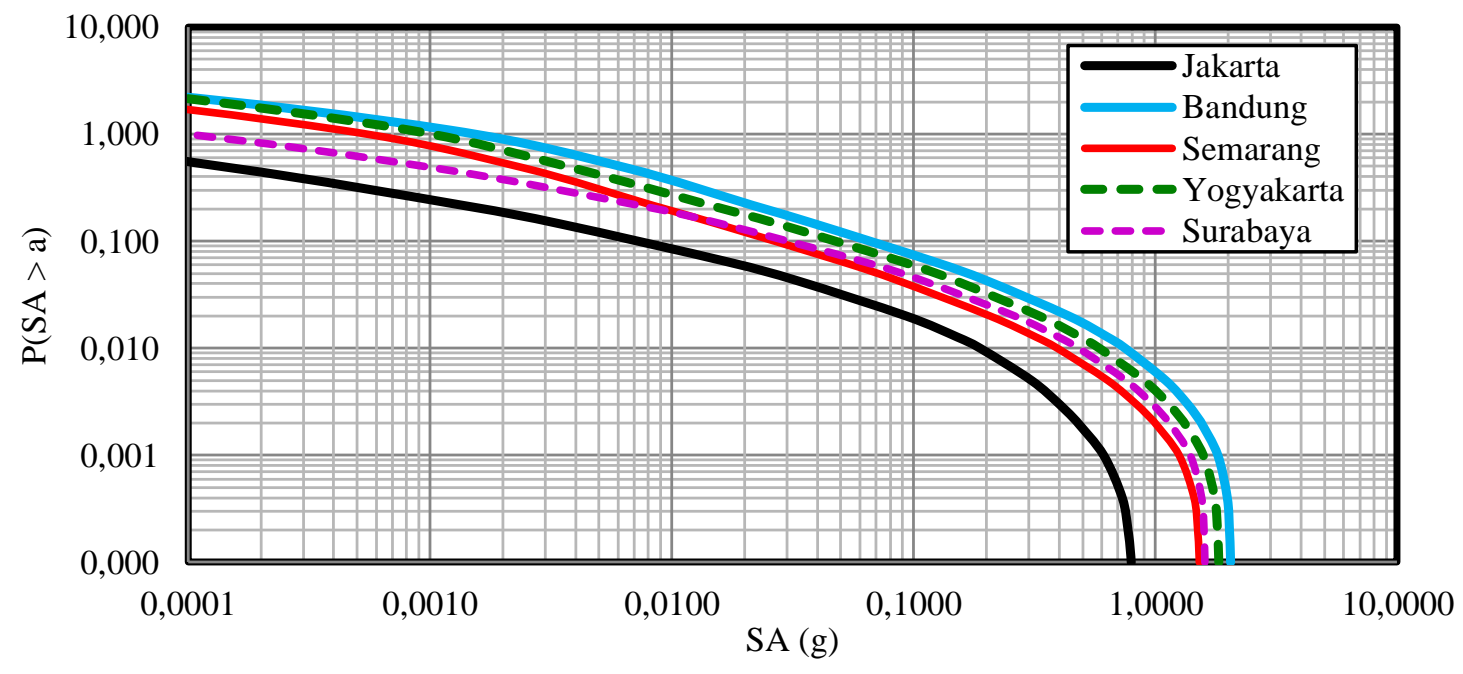

Gambar 2. Kurva hazard 0,2 detik untuk lima kota

Menurut SNI 1726:2012 dan ASCE/SEI 7-16 nilai spektra percepatan di permukaan tanah, $\mathrm{S}_{\mathrm{MS}}$ dan $\mathrm{S}_{\mathrm{M} 1}$, dapat dihitung dengan menggunakan Persamaan 4 dan 5 . $S_{S}$ dan $S_{1}$ pada kedua persamaan tersebut merupakan nilai spektra percepatan periode pendek $(0,2$ detik) dan periode panjang (1 detik) hasil perhitungan spektra $\mathrm{MCE}_{\mathrm{R}}$.

$$
\begin{aligned}
& S_{M S}=F a^{*} S_{S} \\
& S_{M 1}=F v^{*} S_{1}
\end{aligned}
$$

\section{Hasil dan Pembahasan}

Hasil analisis PSHA untuk lima kota besar di Pulau Jawa berbentuk kurva hazard gempa. Gambar 2 menunjukkan kurva hazard gempa untuk lima kota besar di Pulau Jawa untuk spektra 0,2 detik dan Gambar 3 menunjukkan kurva hazard gempa untuk spektra 1 detik. Dari kedua kurva hazard gempa tersebut maka dapat dihitung nilai spektra 0,2 detik dan 1 detik dengan probabilitas $2 \%$ terlampaui selama 50 tahun atau periode ulang gempa 2.500 tahun. Tabel 5 menunjukkan spektra hazard gempa periode 0,2 detik dan 1 detik untuk lima kota besar. Data perhitungan PSHA diambil dari hasil perhitungan dan pembuatan peta hazard gempa tahun 2017. Peta hazard gempa tahun 2017 dihitung untuk seluruh wilayah Indonesia dengan kordinat $\left(92^{\circ} \mathrm{BT}, 8^{\circ} \mathrm{LU}\right)$ sampai $\left(142^{\circ} \mathrm{BT},-12^{\circ} \mathrm{LS}\right)$ dengan interval $0.1^{\circ}$ untuk kedua arah bujur timur (BT) dan lintang utara dan selatan (LU dan LS).

Karena posisi koordinat setiap kota tidak bertepatan atau tidak sama dengan koordinat data hazard gempa tahun 2017 maka data hazard gempa yang dipilih adalah data dari titik terdekat dengan koordinat kelima kota. Nilai spektra percepatan yang dihitung dengan pendekatan PSHA sebagaimana terlihat pada Tabel 5 dihitung dengan probabilitas terlampaui $2 \%$ selama 50 tahun. 


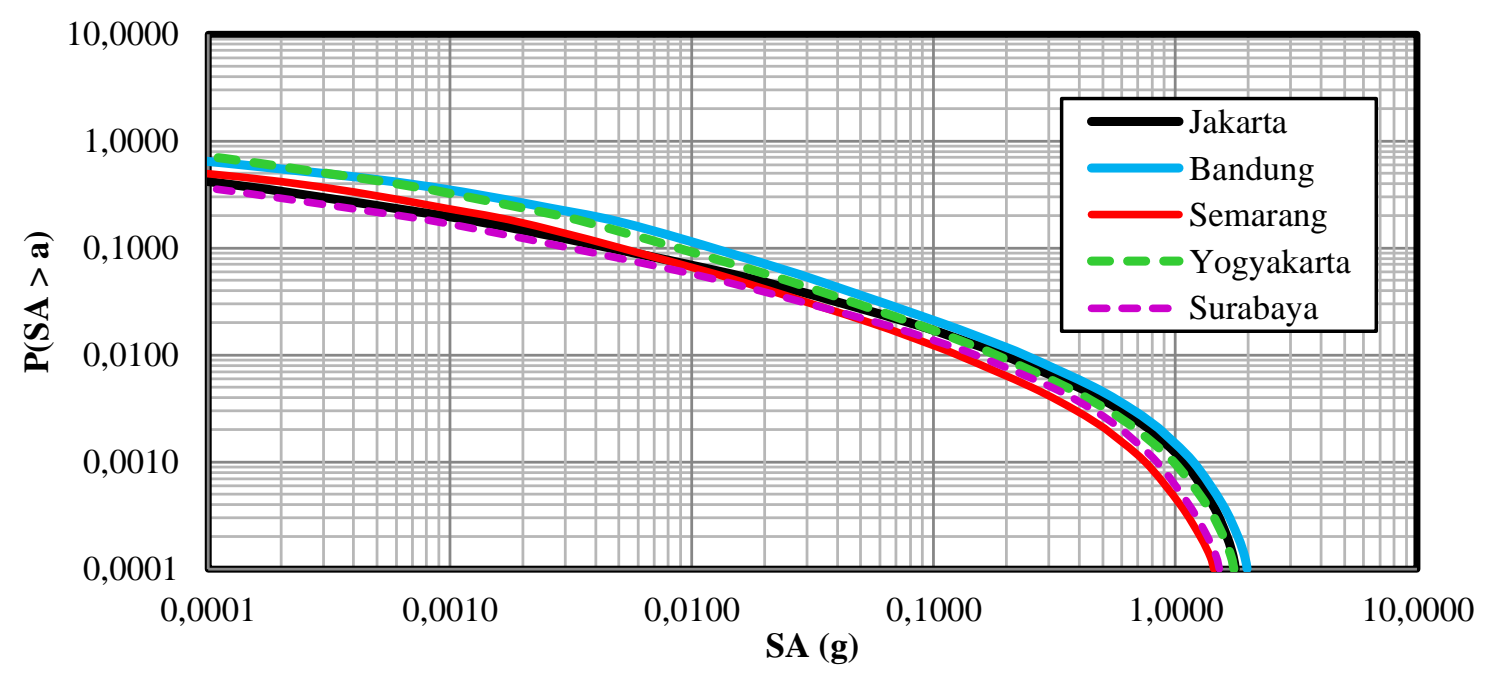

Gambar 3. Kurva hazard 1 detik untuk lima kota

Nilai spektra percepatan dihitung dengan menggunakan kurva hazard gempa 0,2 detik dan 1 detik sebagaimana terlihat pada Gambar 2 dan Gambar 3. Koordinat lima kota besar menggunakan data yang sama dengan data pada SNI 1726:2012.

Tabel 5. Spektra percepatan PSHA di batuan dasar

\begin{tabular}{|c|c|c|c|c|}
\hline \multirow[b]{2}{*}{ Kota } & \multicolumn{2}{|c|}{ Koordinat } & \multicolumn{2}{|c|}{ Spektra PSHA } \\
\hline & Buj & Li & $\begin{array}{c}\mathbf{0 , 2} \\
\text { detik } \\
(\mathrm{g})\end{array}$ & 1 detik \\
\hline Jakarta & 106,865 & $-6,175$ & 0,798 & 0,402 \\
\hline Bandung & 107,619 & $-6,917$ & 1,286 & 0,562 \\
\hline Semarang & 110,438 & $-7,005$ & 0,998 & 0,433 \\
\hline Yogyakarta & 110,350 & $-7,800$ & 1,345 & 0,606 \\
\hline Surabaya & 112,752 & $-7,257$ & 0,717 & 0,334 \\
\hline
\end{tabular}

Tabel 6. Spektra percepatan RTGM di batuan dasar

\begin{tabular}{lcccc}
\hline \multirow{2}{*}{ Kota } & \multicolumn{2}{c}{ Koordinat } & \multicolumn{2}{c}{ Spektra RTGM } \\
\cline { 2 - 5 } & Bujur & Lintang & $\begin{array}{c}\text { 0,2 } \\
\text { detik (g) }\end{array}$ & $\begin{array}{c}\text { detik } \\
\text { (g) }\end{array}$ \\
\hline Jakarta & 106,865 & $-6,175$ & 0,788 & 0,380 \\
Bandung & 107,619 & $-6,917$ & 1,189 & 0,514 \\
Semarang & 110,438 & $-7,005$ & 0,911 & 0,391 \\
Yogyakarta & 110,350 & $-7,800$ & 1,238 & 0,538 \\
Surabaya & 112,752 & $-7,257$ & 0,680 & 0,306 \\
\hline
\end{tabular}

Tabel 6 menunjukkan hasil perhitungan RTGM 0,2 detik dan 1 detik pada lima kota dengan menggunakan target probabilitas keruntuhan bangunan $1 \%$ terlampaui selama 50 tahun dan nilai logaritma standard deviasi " $\beta$ " sebesar 0,65. Pada perhitungan spektra RTGM digunakan nilai faktor arah gempa (direction factor) 1,1 untuk spektra 0,2 detik dan 1,3 untuk spektra 1 detik. Pemilihan ketiga nilai tersebut berbeda dengan yang digunakan pada perhitungan RTGM untuk SNI 1726:2012.

Tabel 7. Spektra percepatan DSHA di batuan dasar

\begin{tabular}{|c|c|c|c|c|}
\hline \multirow[b]{2}{*}{ Kota } & \multicolumn{2}{|c|}{ Koordinat } & \multicolumn{2}{|c|}{ Spektra DSHA } \\
\hline & Bujur & Lintang & $\begin{array}{c}0,2 \\
\text { detik } \\
(\mathrm{g})\end{array}$ & 1 detik \\
\hline Jakarta & 106,865 & $-6,175$ & 0,378 & 0,242 \\
\hline Bandung & 107,619 & $-6,917$ & 1,185 & 0,426 \\
\hline Semarang & 110,438 & $-7,005$ & 0,607 & 0,906 \\
\hline Yogyakarta & 110,350 & $-7,800$ & 1,147 & 0,301 \\
\hline Surabaya & 112,752 & $-7,257$ & 1,415 & 0,426 \\
\hline
\end{tabular}

Tabel 7 menunjukkan hasil analisis hazard gempa determinstik (DSHA) pada lima kota. Hasil perhitungan DSHA merupakan penggabungan dari beberapa sumber gempa di sekitar lima kota besar dengan menggunakan magnitudo gempa maksimum sebagaimana telah digunakan pada perhitungan PSHA dan jarak sumber gempa terdekat. Nilai spektra percepatan DSHA pada Tabel 7 dihitung dengan menggunakan nilai $84^{\text {th }}$ percentile dari nilai mean atau sebesar 1,8 lebih besar dari nilai mean. Nilai direction factor yang digunakan pada perhitungan DSHA untuk spektra 0,2 detik dan 1 detik yaitu masing-masing secara berurutan sebesar 1,1 dan 1,3.

Tabel 8 menunjukkan hasil analisis hazard gempa gabungan RTGM dan deterministik DSHA untuk mencari nilai spektra percepatan $\mathrm{MCE}_{\mathrm{R}} \mathrm{S}_{\mathrm{S}}$ dan $\mathrm{MCE}_{\mathrm{R}} \mathrm{S}_{1}$. Percepatan $\mathrm{MCE}_{\mathrm{R}} \mathrm{S}_{\mathrm{S}}$ dan $\mathrm{S}_{4}$ untuk selanjutnya digunakan untuk perhitungan spektra percepatan di permukaan. Spektra percepatan di permukaan dihitung dengan mengalikan nilai spektra $\mathrm{MCE}_{\mathrm{R}} \mathrm{S}_{\mathrm{S}}$ maupun $\mathrm{MCE}_{\mathrm{R}} \mathrm{S}_{1}$ dengan koefisien situs Fa dan Fv masing-masing untuk spektra 0,2 detik dan 1 detik. Nilai spektra $S_{S}$ dan $S_{1}$ 
sebagaimana terlihat pada tabel tersebut untuk selanjutnya digunakan untuk perhitungan spektra permukaan $S_{M S}$ dan $S_{M 1}$. Spektra $S_{M S}$ dan $S_{M 1}$ dihitung dengan mengalikan nilai koefisien situs $\mathrm{Fa}$ dan Fv dengan nilai spektra $S_{S}$ dan $S_{1}$. Spektra permukaan $S_{M S}$ dan $S_{M 1}$ dihitung dengan menggunakan dua model koefisien situs dari Stewart \& Seyhan (2013) dan SNI 1726:2012.

Tabel 8. Spektra $M_{C} E_{R} S_{s}$ dan $S_{1}$

\begin{tabular}{lcccc}
\hline \multirow{2}{*}{ Kota } & \multicolumn{2}{c}{ Koordinat } & \multicolumn{2}{c}{ Spektra MCER $_{\mathbf{R}}$} \\
\cline { 2 - 5 } & Bujur & Lintang & Ss $(\mathbf{g})$ & S $_{\mathbf{1}}(\mathbf{g})$ \\
\hline Jakarta & 106,865 & $-6,175$ & 0,774 & 0,377 \\
Bandung & 107,619 & $-6,917$ & 1,155 & 0,503 \\
Semarang & 110,438 & $-7,005$ & 0,839 & 0,365 \\
Yogyakarta & 110,350 & $-7,800$ & 1,221 & 0,534 \\
Surabaya & 112,752 & $-7,257$ & 0,708 & 0,313 \\
\hline
\end{tabular}

Tabel 9 sampai 11 menunjukkan hasil perhitungan spektra percepatan di permukaan $\mathrm{S}_{\mathrm{MS}}$ dan $\mathrm{S}_{\mathrm{M} 1}$ masing-masing untuk tiga situs tanah SC (tanah keras), SD (tanah sedang) dan SE (tanah lunak) hasil perkalian nilai koefisien situs dengan nilai $\mathrm{MCE}_{\mathrm{R}} \mathrm{S}_{\mathrm{S}}$ dab $\mathrm{S}_{1}$. Perhitungan $\mathrm{S}_{\mathrm{MS}}$ maupun $\mathrm{S}_{\mathrm{M} 1}$ sebagaimana terlihat pada ketiga tabel tersebut menggunakan koefisien situs dari Stewart \& Seyhan (2013) dan koefisien situs dari SNI 1726:2012.

Dari hasil perhitungan nilai spektra permukaan $S_{M S}$ dan $S_{\mathrm{M} 1}$ sebagaimana terlihat pada Tabel 9 sampai 11 , terlihat bahwa nilai $S_{M S}$ untuk situs tanah SC dan SE dengan menggunakan koefisien situs dari Stewart dan Seyhan (2013) lebih besar dibandingakan dengan hasil perhitungan dengan menggunakan koefisien situs dari SNI 1726:2012. Pada situs tanah SD nilai $\mathrm{S}_{\mathrm{MS}}$ yang dihitung dengan menggunakan koefisien situs dari Stewart \& Seyhan (2013) mempunyai nilai yang sama dengan nilai $\mathrm{S}_{\mathrm{MS}}$ yang dihitung dengan menggunakan koefisien situs SNI 1726:2012.

Tabel 9. Spektra percepatan di permukaan $S_{M S}$ dan $S_{M 1}$ dihitung dengan menggunakan koefisien situs dari Stewart \& Seyhan (2013) dan SNI 1726:2012 untuk tanah SC

\begin{tabular}{lcccc}
\hline \multirow{4}{*}{ Kota } & \multicolumn{2}{c}{$\begin{array}{c}\text { Stewart \& } \\
\text { Seyhan }(\mathbf{2 0 1 3})\end{array}$} & \multicolumn{2}{c}{ SNI } \\
& $\mathbf{1 7 2 6 : 2 0 1 2}$ \\
\cline { 2 - 5 } & SMS $(\mathbf{g})$ & $\begin{array}{c}\text { SM1 } \\
(\mathbf{g})\end{array}$ & $\begin{array}{c}\text { SMS } \\
(\mathbf{g})\end{array}$ & $\begin{array}{c}\text { SM1 } \\
(\mathbf{g})\end{array}$ \\
\hline Jakarta & 1,167 & 0,698 & 0,984 & 0,621 \\
Bandung & 1,386 & 0,748 & 1,155 & 0,665 \\
Semarang & 0,908 & 0,517 & 0,829 & 0,501 \\
Yogyakarta & 1,157 & 0,701 & 0,978 & 0,622 \\
Surabaya & 0,866 & 0,470 & 0,788 & 0,465 \\
\hline
\end{tabular}

Hasil perhitungan $\mathrm{S}_{\mathrm{M} 1}$ untuk situs tanah SC dan SD sebagaimana terlihat pada Tabel 9 dan 10 menunjukkan nilai yang lebih besar jika dihitung dengan menggunakan koefisien situs dari Stewart \& Seyhan (2013) dibandingan dengan menggunakan koefisien situs dari SNI 1726:2012. Kondisi sebaliknya terjadi pada kelas situs SE. sebagaimana terlihat pada Tabel 11. Hasil perhitungan $\mathrm{S}_{\mathrm{M} 1}$ untuk kelas situs SE yang dihitung dengan menggunakan koefisien situs dari Stewart \& Seyhan (2013) menunjukkan nilai yang lebih rendah jika dibandingkan dengan menggunakan koefisien situs dari SNI 1726:2012.

Tabel 10. Spektra percepatan di permukaan $S_{M S}$ dan $S_{M 1}$ dihitung dengan menggunakan

koefisien situs dari Stewart \& Seyhan (2013) dan SNI 1726:2012 untuk tanah SD

\begin{tabular}{lcccc}
\hline \multirow{2}{*}{ Kota } & \multicolumn{2}{c}{$\begin{array}{c}\text { Stewart \& } \\
\text { Seyhan }(\mathbf{2 0 1 3})\end{array}$} & \multicolumn{2}{c}{ SNI 1726:2012 } \\
\cline { 2 - 5 } & $\begin{array}{c}\text { SMS } \\
(\mathbf{g})\end{array}$ & $\begin{array}{c}\text { SM1 } \\
(\mathbf{g})\end{array}$ & $\begin{array}{c}\text { SMS } \\
(\mathbf{g})\end{array}$ & $\begin{array}{c}\text { SM1 } \\
(\mathbf{g})\end{array}$ \\
\hline Jakarta & 0,922 & 0,726 & 0,922 & 0,621 \\
Bandung & 1,197 & 0,903 & 1,197 & 0,772 \\
Semarang & 0,977 & 0,705 & 0,977 & 0,607 \\
Yogyakarta & 1,250 & 0,941 & 1,250 & 0,842 \\
Surabaya & 0,875 & 0,623 & 0,875 & 0,554 \\
\hline
\end{tabular}

Tabel 11. Spektra percepatan di permukaan $S_{M S}$ dan $S_{M 1}$ dihitung dengan menggunakan koefisien situs dari Stewart \& Seyhan (2013) dan SNI 1726:2012 untuk tanah SE

\begin{tabular}{lcccc}
\hline \multirow{2}{*}{ Kota } & \multicolumn{2}{c}{$\begin{array}{c}\text { Stewart \& } \\
\text { Seyhan }(\mathbf{2 0 1 3})\end{array}$} & \multicolumn{2}{c}{ SNI 1726:2012 } \\
\cline { 2 - 5 } & $\begin{array}{c}\mathbf{S}_{\mathbf{M S}} \\
\mathbf{( g )}\end{array}$ & $\begin{array}{c}\mathbf{S}_{\mathbf{M 1}} \\
\mathbf{( g )}\end{array}$ & $\begin{array}{c}\text { S } \\
\mathbf{( g )}\end{array}$ & $\begin{array}{c}\text { S } \\
\mathbf{( g 1}\end{array}$ \\
\hline Jakarta & 0,993 & 0,939 & 0,907 & 0,940 \\
Bandung & 1,123 & 1,103 & 1,040 & 1,181 \\
Semarang & 1,031 & 0,923 & 0,913 & 0,923 \\
Yogyakarta & 1,134 & 1,135 & 1,076 & 1,199 \\
Surabaya & 0,972 & 0,859 & 0,911 & 0,858 \\
\hline
\end{tabular}

Perbedaan (peningkatan atau penurunan) yang timbul akibat penggunaan kedua model koefisien situs untuk tiga situs tanah SC, SD dan SE dapat dilihat pada Tabel 12 sampai 14. Tanda "+" atau ". “ pada ketiga tabel tersebut menunjukkan peningkatan atau penurunan nilai $S_{M S}$ atau $S_{M 1}$ yang dihitung dengan koefisien situs dari Stewart \& Seyhan (2013) dibandingkan terhadap koefisien situs dari SNI 1726:2012.

Dari hasil perhitungan sebagaimana terlihat pada Tabel 12 nilai $S_{M S}$ mengalami peningkatan maksimum sebesar $20 \%$ dan minimum sebesar $9,53 \%$ atau rata-rata sebesar $15,27 \%$ untuk nilai $S_{M S}$ situs tanah SC. Untuk spektra $\mathrm{S}_{\mathrm{M} 1}$ terjadi peningkatan maksimum sebesar $12,48 \%$ dan minimum sebesar $1,08 \%$ dengan rata-rata sebesar $8,37 \%$. Dengan mengabaikan tanda "+" dan “_" atau perubahan mutlak terlihat nilai $S_{M S}$ dan $S_{M 1}$ secara 
rata-rata untuk lima kota besar untuk situs tanah SC berbeda sebesar $8 \%$ sampai $15 \%$.

Tabel 12. Perbedaan nilai $S_{M s}$ dan $S_{M 1}$ yang dihitung dengan menggunakan koefisien situs dari Stewart \& Seyhan (2013) terhadap SNI 1726:2012 untuk tanah SC

\begin{tabular}{lrr}
\hline \multirow{2}{*}{ Kota } & \multicolumn{2}{c}{ Perbedaan (\%) } \\
\cline { 2 - 3 } \multicolumn{1}{c}{ Sor } & \multicolumn{1}{c}{ SM1 $_{\mathbf{M S}}$} \\
\hline Jakarta & $+18,60$ & $+12,40$ \\
Bandung & $+20,00$ & $+12,48$ \\
Semarang & $+9,53$ & $+3,19$ \\
Yogyakarta & $+18,30$ & $+12,70$ \\
Surabaya & $+9,90$ & $+1,08$ \\
Rata-rata & $+15,27$ & $+8,37$ \\
\hline
\end{tabular}

Kajian yang sama juga dilakukan terhadap situs tanah SD pada lima kota besar di Pulau Jawa, Sebagaimana terlihat pada Tabel 13, spektra $\mathrm{S}_{\mathrm{MS}}$ yang dihitung dengan menggunakan koefisien situs dari Stewart \& Seyhan (2013) maupun SNI 1726:2012 menunjukkan nilai yang sama atau tidak mengalami perubahan. Kondisi ini disebabkan karena nilai koefisien situs dari Stewart \& Seyhan (2013) untuk perhitungan $S_{M S}$ untuk situs tanah SD sama dengan koefisien situs dari SNI 1726:2012. Kondisi berbeda terjadi pada hasil perhitungan spektra $\mathrm{S}_{\mathrm{M} 1}$. Spektra $\mathrm{S}_{\mathrm{M} 1}$ yang dihitung dengan menggunakan koefisien situs dari Stewart \& Seyhan (2013) lebih besar dibandingan dengan spektra $S_{M 1}$ yang dihitung menggunakan koefisien situs dari SNI 1726:2012. Peningkatan spektra $\mathrm{S}_{\mathrm{MI}}$ minimum sebesar $11,76 \%$ dan maksimum sebesar $16,97 \%$ atau rata-rata sebesar $14,85 \%$.

Tabel 13. Perbedaan nilai $S_{M S}$ dan $S_{M 1}$ yang dihitung dengan menggunakan koefisien situs dari Stewart \& Seyhan (2013) terhadap SNI 1726:2012 untuk tanah SD

\begin{tabular}{lcc}
\hline \multirow{2}{*}{\multicolumn{1}{c}{ Kota }} & \multicolumn{2}{c}{ Perbedaan (\%) } \\
\cline { 2 - 3 } & S & SM1 $_{\mathbf{M S}}$ \\
\hline Jakarta & 0,00 & $+16,91$ \\
Bandung & 0,00 & $+16,97$ \\
Semarang & 0,00 & $+16,14$ \\
Yogyakarta & 0,00 & $+11,76$ \\
Surabaya & 0,00 & $+12,45$ \\
Rata-rata & 0,00 & $+14,85$ \\
\hline
\end{tabular}

Hasil perhitungan nilai $\mathrm{S}_{\mathrm{MS}}$ untuk situs tanah SE di lima kota sebgaimana terlihat pada Tabel 14 menunjukkan adanya peningkatan jika menggunakan koefisen situs dari Stewart \& Seyhan (2013) dibandingkan jika menggunakan koefisien situs dari SNI 1726:2012. Besarnya peningkatan spektra $\mathrm{S}_{\mathrm{MS}}$ minimum sebesar $3,28 \%$ dan maksimum sebesar $22,14 \%$ atau rata-rata sebesar $12,96 \%$. Berbeda dengan spektra $S_{M S}$, nilai spektra $\mathrm{S}_{\mathrm{M} 1}$ yang dihitung menggunakan koefisien situs dari Stewart \& Seyhan (2013) mengalami penurunan minimum sebesar $1,94 \%$ dan maksimum sebesar $11,47 \%$ atau rata-rata sebesar $5,79 \%$.

Hasil kajian terhadap penggunaan koefisien situs dari Stewart \& Seyhan (2013) setelah di bandingkan dengan koefisien situs dari SNI 1726:2012 untuk situs tanah SC, SD dan SE secara rata-rata menunjukkan perbedaan sebesar $\pm 15 \%$. Dari hasil perhitungan nilai $S_{M S}$ dan $S_{M 1}$ pada lima kota memberi gambaran tentang perubahan atau perbedaan yang signifikan sekiranya pada perhitungan kedua spektra percepatan permukaan tersebut menggunakan nilai koefisien situs dari ASCE/SEI 7-16. Kajian yang lebih lengkap tentang pengaruh model SSA pada penentuan nilai koefisien situs tanah lunak SE perlu dilakukan untuk melihat lebih jelas perbedaan penggunaan metode SSA dengan menggunakan koefisien situs dari Stewart \& Seyhan (2013).

Tabel 14. Perbedaan nilai $S_{M S}$ dan $S_{M 1}$ yang dihitung dengan menggunakan koefisien situs dari Stewart \& Seyhan (2013) terhadap SNI 1726:2012 untuk tanah SE

\begin{tabular}{lrr}
\hline \multirow{2}{*}{\multicolumn{1}{c}{ Kota }} & \multicolumn{2}{c}{ Perbedaan $(\%)$} \\
\cline { 2 - 3 } & \multicolumn{1}{c}{ S $\mathbf{M S}$} & \multicolumn{1}{c}{ S } \\
\hline Jakarta & $+22,14$ & $-4,18$ \\
Bandung & $+7,98$ & $-8,62$ \\
Semarang & $+17,03$ & $-2,74$ \\
Yogyakarta & $+3,28$ & $-11,47$ \\
Surabaya & $+14,35$ & $-1,94$ \\
Rata-rata & $+12,96$ & $-5,79$ \\
\hline
\end{tabular}

\section{Kesimpulan}

Peraturan perencanaan bangunan tahan gempa di Indonesia (SNI 1726:2012) perlu dikaji ulang sejalan dengan perubahan yang ada pada peta gempa Indonesia (Peta Sumber dan Bahaya Gempa Indonesia tahun 2017). Peta $M \mathrm{MCE}_{\mathrm{R}} \mathrm{S}_{\mathrm{S}}$ and $\mathrm{S}_{1}$ yang ada pada SNI 1726:2012 dikembangkan dari peta gempa Indonesia tahun 2010. Perlu dilakukan kajian tentang peta $M C E_{R} S_{S}$ dan $S_{1}$ baru diseluruh wilayah Indonesia sebagai pengganti peta $\mathrm{MCE}_{R} \mathrm{~S}_{S}$ dan $S_{1}$ yang ada pada SNI 1726:2012.

Perubahan yang muncul pada pengembangan peta $\mathrm{MCE}_{\mathrm{R}} \mathrm{S}_{\mathrm{S}}$ dan $\mathrm{S}_{1}$ di seluruh wilayah Indonesia akibat dari perubahan data gempa dan data sumber gempa di seluruh wilayah Indonesia. Perubahan nilai direction factor dan nilai standard deviasi $(\beta)$ yang digunakan pada perhitungan MCER $S_{S}$ dan $S_{1}$ menyebabkan terjadinya perubahan kedua spektra percepatan tersebaut dibandingkan nilai lama yang ada pada SNI 1726:2012.

Koefisien situs yang dikembangkan untuk perhitungan spektra percepatan di permukaan $S_{M S}$ dan $S_{M 1}$ pada SNI 1726:2012 mengabdopsi secara 
langsung konsep perhitungan spektra percepatan $\mathrm{S}_{\mathrm{MS}}$ dan $\mathrm{S}_{\mathrm{M} 1}$ dari peraturan ASCE/SEI 7-10. ASCE/SEI 7-10 sebagai acuan pembuatan SNI 1726:2012 telah berubah menjadi ASCE/SEI 7-16. Salah satu perubahan penting yang terdapat pada ASCE/SEI 7-16 dan sulit diadopsi pada perubahan SNI 1726:2012 adalah perubahan cara perhitungan koefisien situs untuk perhitungan spektra $S_{M S}$ dan $\mathrm{S}_{\mathrm{M} 1}$ tanah lunak $(\mathrm{SE})$.

Pengembangan SNI 1726:2012, membutuhkan metoda lain untuk mempermudah perhitungan koefisien situs tanah maupun perhitungan $\mathrm{S}_{\mathrm{MS}}$ dan $\mathrm{S}_{\mathrm{M} 1}$ untuk situs tanah SE. Hasil kajian perhitungan spektra $S_{M S}$ dan $S_{M 1}$ di lima kota besar di Pulau Jawa menunjukkan bahwa koefisien situs yang dikembangkan oleh Stewart \& Seyhan (2013) dapat digunakan di Indonesia karena lebih mudah untuk diaplikasikan.

Koefisien situs tersebut juga digunakan pada ASCE/SEI 7-16 kecuali untuk situs tanah SE. Hasil kajian perhitungan spektra $S_{M S}$ pada lima kota besar di Pulau Jawa (Jakarta, Bandung, Semarang, Yogyakarta dan Surabaya) untuk situs tanah SC, SD dan SE dengan menggunakan koefisien situs dari Stewart \& Seyhan (2013) serta membandingkannya dengan koefisien situs dari SNI 1726:2012 menunjukkan adanya perubahan secara signifikan dengan perbedaan atau kenaikan secara rata-rata sebesar $15 \%$ untuk tanah SC dan $13 \%$ untuk tanah SE. Untuk tanah SD nilai spektra $S_{\mathrm{MS}}$ pada kelima kota tersebut tidak mengalami perubahan. Hal ini menunjukkan bahwa untuk pengembangan SNI 1726:2012 atau hitungan nilai spektra permukaan $\mathrm{S}_{\mathrm{MS}}$ dapat menggunakan nilai koefisien situs baru dari Stewart \& Seyhan (2013) sebagai pengganti koefisien situs yang ada pada ASCE/SEI 7-16.

Hasil perhitungan nilai spektra permukaan $S_{M 1}$ pada lima kota besar di Pulau Jawa untuk situs tanah SC dan SD dengan menggunakan koefisien situs dari Stewart \& Seyhan (2013) maupun ASCE/SEI 7-16 mengalami kenaikan secara rata-rata sebesar $8 \%$ untuk tanah SC dan 15\% untuk tanah SD. Untuk situs tanah SE perhitungan spektra permukaan $\mathrm{S}_{\mathrm{M} 1}$ jika menggunakan koefisien situs dari Stewart \& Seyhan (2013) mengalami penurunan secara ratarata sebesar $6 \%$. Adanya kenaikan nilai spektra permukaan $\mathrm{S}_{\mathrm{MS}}$ sebesar $13 \%$ dan penurunan nilai $\mathrm{S}_{\mathrm{M} 1}$ sebesar 6\% utnuk tanah SE maka nilai koefisien situs dari Stewart \& Seyhan (2013) dapat digunakan sebagai pengganti koefisien situs yang ada pada SNI 1726:2012.

Karena adanya perbedaan pada hasil perhitungan spektra $S_{M S}$ dan $S_{M 1}$ pada lima kota besar di Pulau Jawa, penggunaan koefisien situs lama dari SNI 1726:2012 atau koefisien situs dari Stewart \&
Seyhan (2013) harus melaui hasil kajian untuk seluruh kota besar yang ada di Indonesia atau seluruh wilayah di Indonesia. Hasil kajian ini diharapkan memberikan gambaran secara menyeluruh tentang perbedaan yang diperoleh sekiranya koefisien situs dari Stewart \& Seyhan (2013) akan digunakan sebagai pengganti dari koefisien situs yang ada pada SNI 1726:2012.

ASCE/SEI 7-16 telah memperkenalkan metode SSA untuk perhitungan koefisien situs atau spektra percepatan tanah di permukaan untuk situs tanah SE. Studi tentang pemanfaatan metode ini perlu dilakukan di seluruh wilayah Indonesia. Hasil kajian tersebut akan memberikan gambaran tentang seberapa besar perbedaan yang akan diperoleh seandainya spektra $S_{M S}$ dan $S_{M 1}$ dihitung dengan metode SSA dibandingkan dengan penggunaan koefisien situs dari Stewart \& Seyhan (2013) maupun dari SNI 1726:2012. Kajian ini sangat penting untuk diperkenalkan kepada para ahli dibidang Teknik Sipil agar mengenal lebih dekat tentang metode SSA untuk mendapatkan nilai spektra percepatan di permukaan.

\section{Ucapan Terima Kasih}

Ucapan terima kasih disampaikan kepada Fakultas Teknik, Universitas Diponegoro atas bantuan pembiayaan pada penelitian ini melalui program Hibah Penelitian Strategis tahun 2019. Ucapan terima kasih juga disampaikan kepada Pusat Studi Gempa Nasional (PUSGEN), Pusat Litbang Perumahan dan Pemukiman, Kemeterian Pekerjaan Umum dan Perumahan Rakyat atas bantuan penyediaan data hazard gempa seluruh Indonesia.

\section{Daftar Pustaka}

Abrahamson, N., Gregor, N., \& Addo, K. (2016). BC Hydro Ground Motion Prediction Equations for Subduction Earthquakes. Earthquake Spectra, 32(1), 23-44.

ASCE/SEI 07-16 (2017). Minimum design loads and associated criteria for buildings and other structures. American Society of Civil Engineers.

Atkinson, G. M., \& Boore, D. M. (2003). Empirical Ground-Motion Relations for Subduction-Zone Earthquakes and Their Application to Cascadia and Other Regions. Bulletin of the Seismological Society of America, 93(4), 1703-1729.

Boore, D. M., \& Atkinson, G. M. (2008). GroundMotion Prediction Equations for The Average Horizontal Component Of PGA, PGV, and 5\%Damped PSA at Spectral Periods Between $0.01 \mathrm{~s}$ and 10.0 s. Earthquake Spectra, 24(1), 99-138. 
Campbell, K. W., \& Bozorgnia, Y. (2008). NGA Ground Motion Model for The Geometric Mean Horizontal Component Of PGA, PGV, PGD and 5\% Damped Linear Elastic Response Spectra for Periods Ranging From 0.01 to 10 s. Earthquake Spectra, 24(1), 139-171.

Chiou, B. S. J. \& Young, R. R. (2008). NGA model for average horizontal component of peak ground motion and response spectra. PEER 2008/2009, Pasific Earthquake Engineering Research Center, College of Engineering, University of California, Berkeley.

Irsyam M., Dangkua D. T., Kusumastuti D. \& Kertapati E. (2007). Methodology of Site-Specific Seismic Hazard Analysis for Important Civil Structure. Civil Engineering Dimensions, 9(2), 103112.

Leyendecker, E. V., Hunt, R. J., Frankel, A. D., \& Rukstales, K. S. (2000). Development of Maximum Considered Earthquake Ground Motion Maps. Earthquake Spectra, 16(1), 21-40.

Luco, N., Ellingwood, B. R., Hamburger, R. O., Hooper, J. D., Kimbal, J. K. \& Kircher, C. A. (2007, September). Risk-Targeted versus current seismic design maps for the conterminous United States, Paper Presented at SEAOC 2007, Structural Engineers Association of California, California.

McGuire R.K. (1995). Probabilistic Seismic Hazard Analysis and Design Earthquakes, Closing the Loop, Bulletin of The Seismological Society of America, 85(5), 1275-1284.

Partono, W., Wardani, S. P. R., Irsyam, M., \& Maarif, S. (2015). Development of seismic microzonation maps of Semarang, Indonesia. Jurnal Teknologi, 77(11), 99-107.

Pusat Studi Gempa Nasional (PUSGEN), (2017). Peta sumber dan bahaya gempa Indonesia tahun 2017. Pusat Litbang Perumahan dan Pemukiman, Badan Penelitian dan Pengembangan, Indonesia:
Kementerian Pekerjaan Umum dan Perumahan Rakyat.

SNI 1726:2012 (2012). Tata cara perencanaan ketahanan gempa untuk struktural bangunan gedung dan non gedung, Indonesia: Badan Standardisasi Nasional.

Sengara, I. W., Irsyam, M., Sidi, I. D., Mulia, A., Asrurifak, M., \& Hutabarat, D. (2015, July). Development of Earthquake Risk-Targeted Groundmotions for Indonesian Earthquake Resistance Building Code SNI-1726-2012. Paper presented at 12th International Conference on Applications of Statistics and Probability in Civil Engineering (ICASP12). Vancouver Canada. July, 12-15.

Sidi I. D. (2011). Hazard analysis and probability based factor of safety, Research Report, Structural Engineering Division, Faculty of Civil and Environmental Engineering, Indonesia: Institut Teknologi Bandung.

Shiuly A., Sahu R.B. \& Mandal S. (2017). Site Specific Seismic Hazard Analysis and Determination of Response Spectra of Kolkata for Maximum Considered Earthquake. Journal of Geophysics and Engineering, 14(3), 466-477.

Stewart J. A. \& Seyhan E. (2013). Semi-Empirical Nonlinear Site Amplification and its Application in NEHRP Site Factors, Pasific Earthquake Engineering Research Center (PEER) Report 2013/13, Berkelay: University of California.

Zhao, J. X., Irikura, K., Zhang, J., Fukushima, Y., Somerville, P. G., Asano, A. \& Ogawa, H. (2006). An Empirical Site-Classification Method for Strong-Motion Stations in Japan using $\mathrm{H} / \mathrm{V}$ Response Spectral Ratio. Bulletin of the Seismological Society of America, 96(3), 914-925.

Youngs, R. R., Chiou, S. J., Silva, W. J., \& Humphrey, J. R. (1997). Strong Ground Motion Attenuation Relationships for Subduction Zone Earthquakes. Seismological Research Letters, 68(1), 58-73. 